
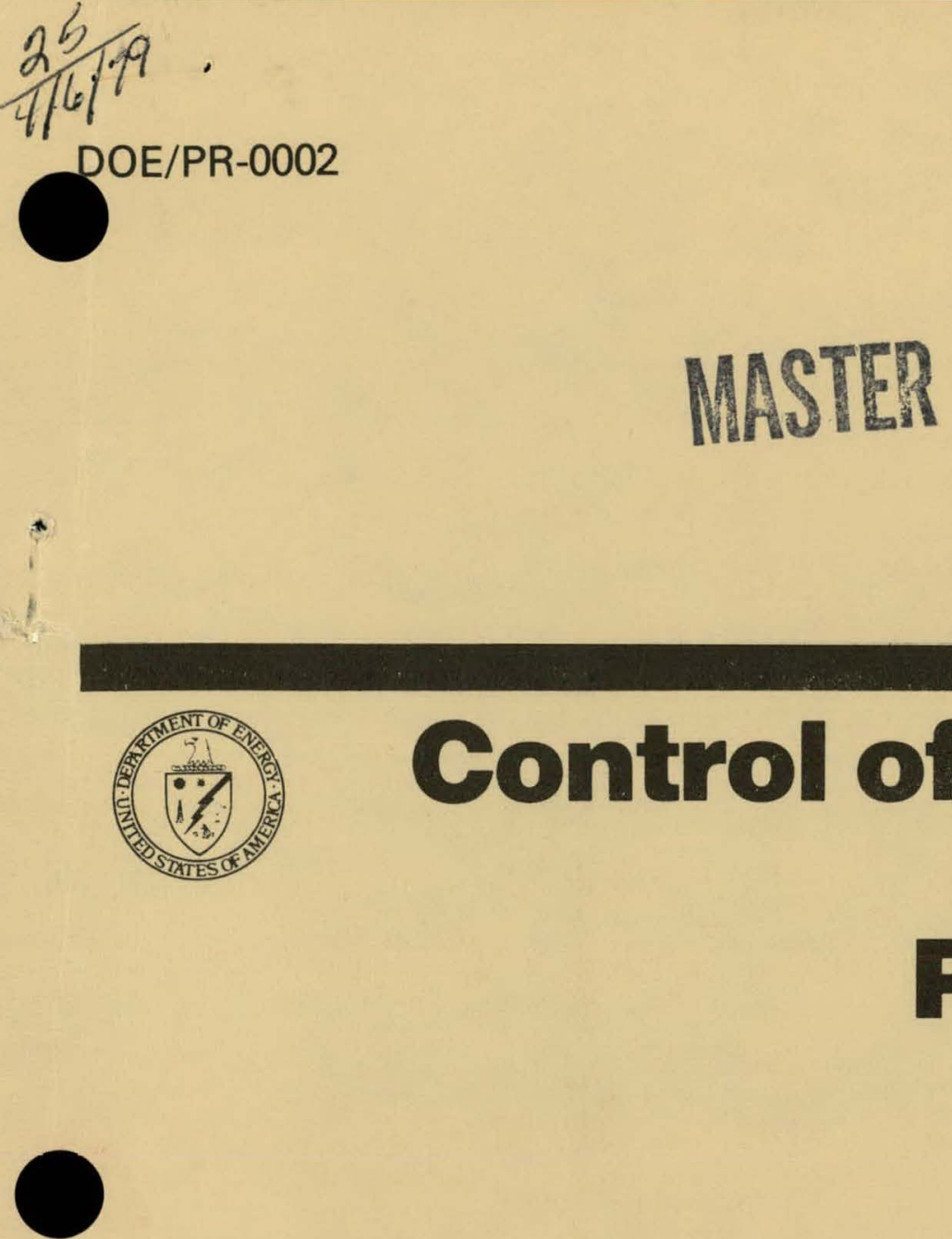

\title{
Control of Government Property in Possession of Contractors
}

December 1977

\section{U.S. Department of Energy \\ Procurement and \\ Contracts Management \\ Directorate}




\section{DISCLAIMER}

This report was prepared as an account of work sponsored by an agency of the United States Government. Neither the United States Government nor any agency Thereof, nor any of their employees, makes any warranty, express or implied, or assumes any legal liability or responsibility for the accuracy, completeness, or usefulness of any information, apparatus, product, or process disclosed, or represents that its use would not infringe privately owned rights. Reference herein to any specific commercial product, process, or service by trade name, trademark, manufacturer, or otherwise does not necessarily constitute or imply its endorsement, recommendation, or favoring by the United States Government or any agency thereof. The views and opinions of authors expressed herein do not necessarily state or reflect those of the United States Government or any agency thereof. 


\section{DISCLAIMER}

Portions of this document may be illegible in electronic image products. Images are produced from the best available original document. 
Available from:

National Technical Information Service (NTIS) U.S. Department of Commerce 5285 Port Royal Road Springfield, Virginia 22161

Price: Printed copy: $\$ 4.50$

Microfiche: $\$ 3.00$ 


\section{Control of Government Property in Possession of Contractors}

December 1977

U.S. Department of Energy

Procurement and Contracts Management

Directorate

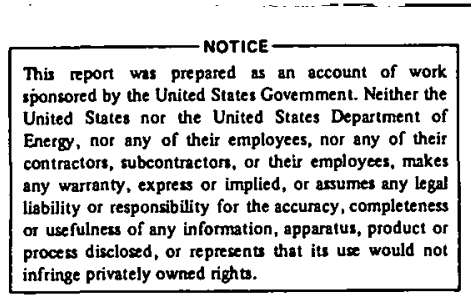


I.

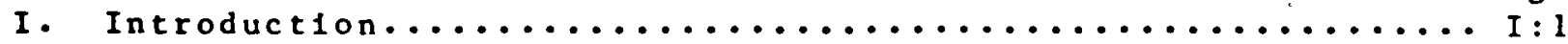

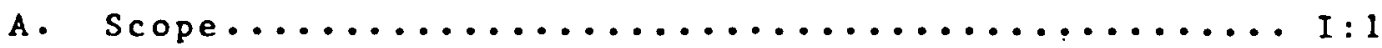

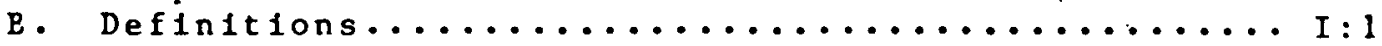

1. DOE Property Administrator.................. I: I

2. Government Personal Property............... I 1

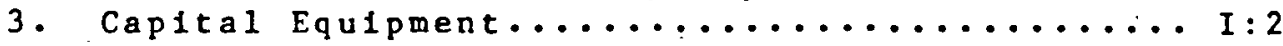

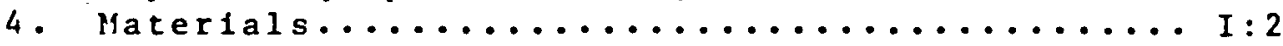

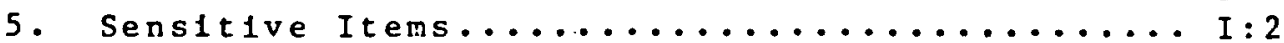

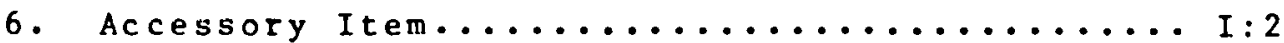

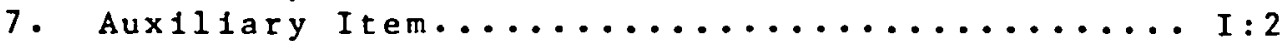

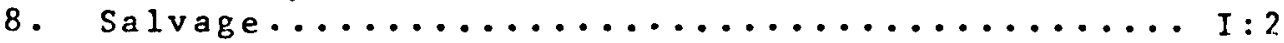

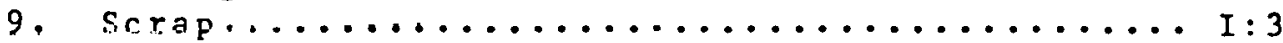

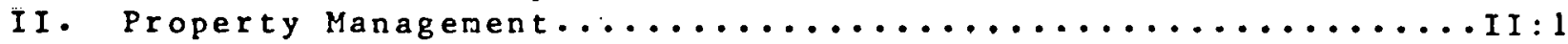

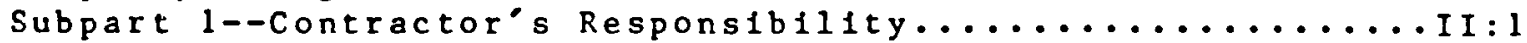

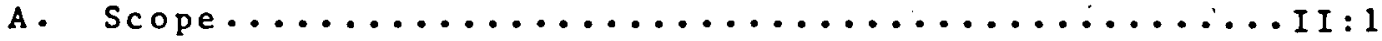

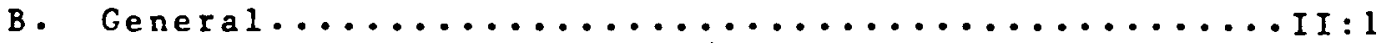

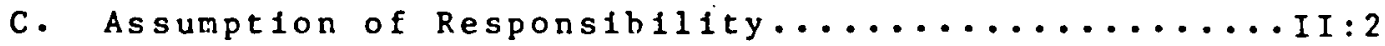

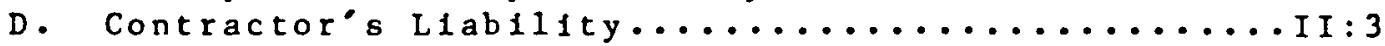

E. Segregation of Government-owned Property ......... II:3

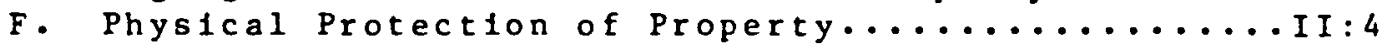

G. Control of Sensitive Items of Property.......... II:4

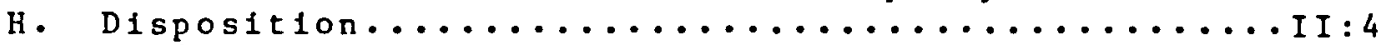

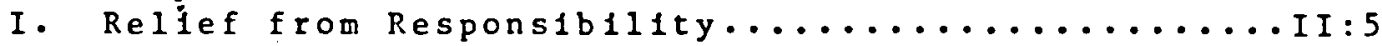

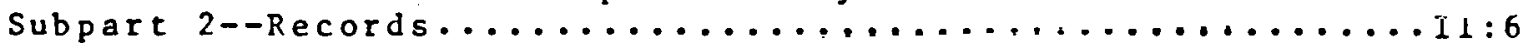

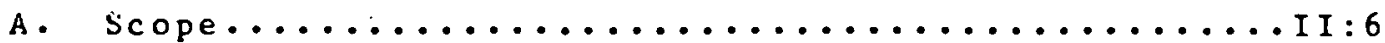

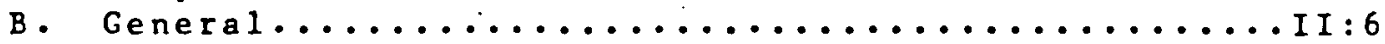

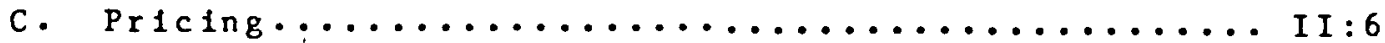

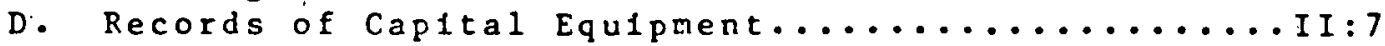

E. Records of liaterials Maintained in stock........ II:8

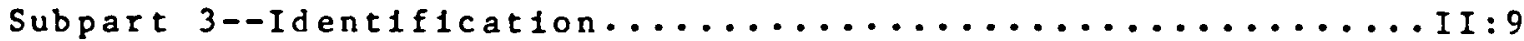

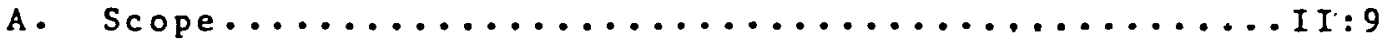

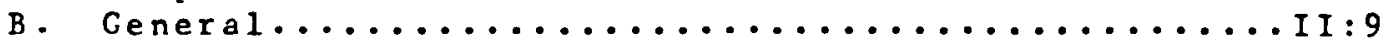

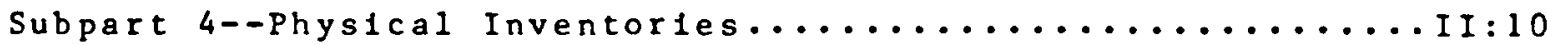

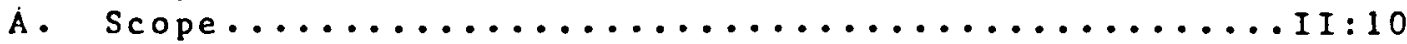

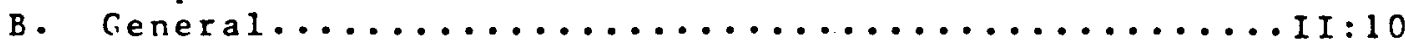

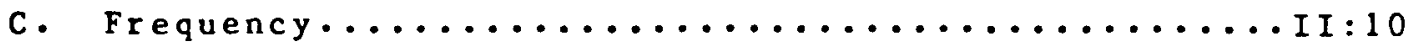

D. Reporting Results of Inventories............... II: 10

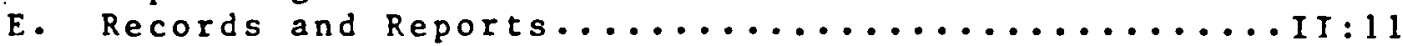

F. Inventories Upon Teritination or Completion....... II:11

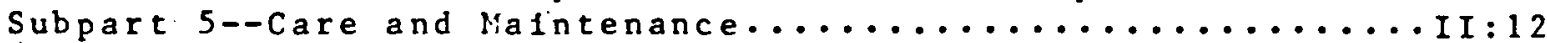

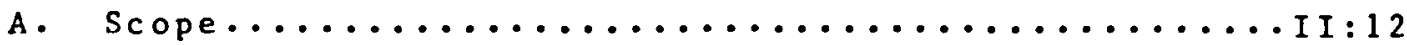

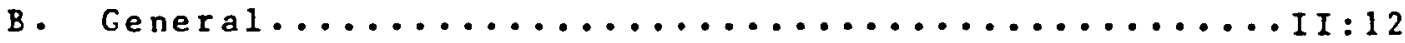

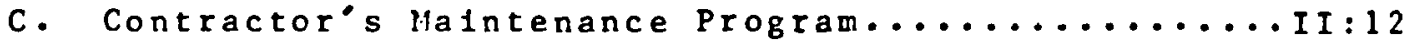

Subpart 6--Ut111zation, D1sposal and Retirement........... II

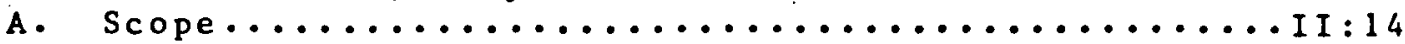


B. General.............................. II:14

C. Maximum Use of Property................... II: 14

D. Disposa1............................. II: 14

E. Ret1rement of Property.................... II: 14

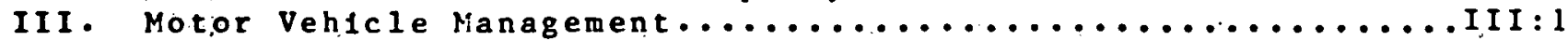

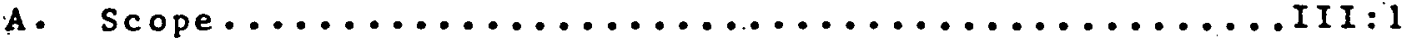

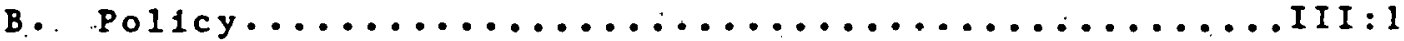

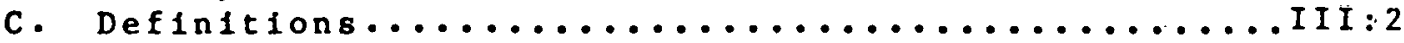

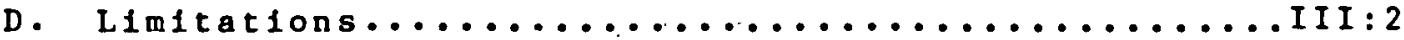

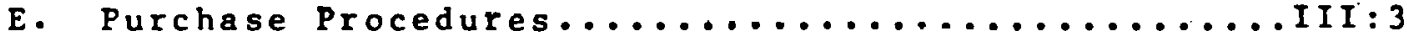

F. Use of GSA Interagency llotor Pools.............. II:4

G. Tags, Legend and Identification................ II:5

H. Maintenance............................. II: 6

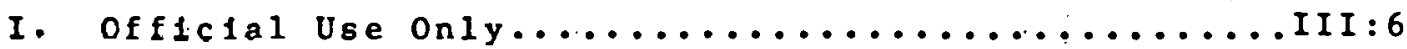

J. Reports.............................. . II 6

K. Alrcraft.................................... 6 
This Guide, "Control of Government Property in Possession of Contractors," has been developed in order to standardize the administration of Government property provided under a DOE contract. This Guide does not apply to fixed-price supply or construction contracts, transportation contracts, grants, cooperative agreements, contracts with state and local governments, special research support agreements, or to cost refmbursement type contractors operating DOE-owned

factitites $\left(\mathrm{COCO}^{\circ} \mathrm{s}\right)$.

- It is intended that this publication be furnished to applicable contractore ao a gulde to DOÉs requirements pertaining to the management and control of Government property in their possession. 
CONTROL OF GOVERINENT PROPERTY IN POSSESSION

OF CONTRACTORS

PART I

INTRODUCTION

A. Scope

Th1s Guide sets forth the basic requirements to be observed by contractors in establishing and maintaining control over Government property, lncluding motor vehicles, provided pursuant to a contract with the U.S. Department of Energy (DOE). In the event of any Inconsistency between this Guide and the contract under which the Government property is provided, the terms of the contract shall govern.

B. Definitions (for purpose of this Guide)

1. DOF. Property Adrinistrator: The 1ndividual designated by the Contracting officer to administei the cuncract requirements and obligations relative to Government property. He $1 \mathrm{~s}$ an authorized representative of the Contracting officer. When a specific individual has not been designated as the Property Administrator, the Contracting officer is the Property Administrator.

2. Government personal property: All property provided at Government expense for performance of the contract, regardless of the method by which it is provided, including rented or leased equipment, except real property, records of the Federal Covernment, nuclear and special source materials, and atomic weapons and by-product materials.

(a) Government-furnished proper:y is property in the possession of, or acquired directly by, the Government and subsequently delivered or otherwise made avaliable to the contractor for use in performance of the contract. 
(b) Contractor-acquired Government property 18 $\therefore$ property procured or otherwise provided by the contractor, the cost of which lis refmbursable under the contract.

3. Capita1 Equ1pment: Property ftems having a unit acquisition cost of generally $\$ 500.00$ or more and an anticlpated service 11 fe of one (1) year or longer, are not properly chargeable to bulldings or utflities, and having the potential for maintaining their integrity as capital items, i.e., not expendable due to use.

4. Haterials: Property which may be incorporated into or actached to an end ltem to be delivered under a contract or which may be consumed in the performance of a contract. It includes, but is not $11 \mathrm{~m} 1 \mathrm{ted}$ to, raw and processed material, parts, components, assemblies, or supplies.

5. Sensitive Items: Property items which, regardless of acquisition cost, are of the type most easily appropriated for personal use, or can be readily converted to cash, and therefore are subject to record control and special safeguards at all times. Examples are cameras, binoculars, radios, power hand tools, calculators, typewriters, and similar ltems.

6. Accessory Item: An item which fac1litates or enhances the operation of equipment but which is not essential for 1 ts operation, such as remote control devices.

7. Aux111ary Item: An 1tem without wh1ch the bas1c unit cannot operate, such as motors for pumps and machine tools.

8. Salvage: Personal property that has some value in excess of its basic material content but which is in such condition that it has no reasonable prospect of use for any purpose as a unit and 1 ts repair or rehabilitation for use is clearly impracticable. Repairs or rehabilitation estimated to cost in excess of 65 percent of acquisition cost would be considered "clearly Impracticable." 
$-I: 3-$

9. Scrap: Material that has no value except for its basic material content.

, 
PART I I

PROPERTY MANAGEMENT

Subpart 1--Contractor's Responsib111ty

\section{A. Scope}

This subpart covers, to the extent not otherwise provided in the contract, the duties and responsibilities of the contractor with respect to the control of Government property., both physlcally and administratively; and the liability of the contractor for Government property lost, damaged, destroyed, or for which the contractor is otherwise unable to account.

\section{B. Genera1}

The contractor shall be responstble for all Government property in his possession of control in accordance with the provisluns of the contract, including property provided under such contract which may be in the possession or control of a subcontractor. The contractor shall establish and malntaln a system (1n accordance with the provisions of this Guide) to control, protect, preserve and maintaln all Government property. Th1s system shall be reviewed and, if satisfactory, approved In writing by the Property Administrator. The contractor shall maintaln and make avallable such records as are required by Part II, Subpart 2, of this Gulde and must account for all Government property unt 11 relieved of responsibility in accordance with procedures set forth in this subpart. Liability for loss, damage, or Improper use of property in a given instance will necessarily depend upon all the circumstances surrounding the particular case and will be determined in accordance with the provisions of the contract. The contractor shall furnish all data necessary to substantiate any request for discharge from respons1b111ty. 
1. The contractor shall require any of his subcontractors who have been provided Government property to comply with the provisions of this Guide. Procedures for assuring subcontractor compliance shall be included in the contractor's approved property control system.

2. In the event any portion of the contractor's property control system is found to be inadequate upon review by the DOE Property Administrator, necessary corrective action will be accomplished by the contractor prior to approval of the system. When agreement as to adequacy of control or corrective action can not be reached between the contractor and the property. Administrator, the matter will be referred to the Contracting officer.

3. The property records and the premises where any Government property is located must be accessible to the Property Administrator or other athorized representatives at all reasonable times. The contractor's property control system is subject to audit by. the Government as often as c1rcumstances warrant, during the contract's performance, at its completion or termination, or at any time. thereafter while the contractor is required to retain the contract records. All these records, including related correspondence, shall be made avaliable to the auditors.

\section{Assumption of Respons1b111ty}

The contractor becomes responsible for Government furnished property upon its delivery into the contractor"s custody. For contractor-acquired Government property, the contractor assumes responsibility in accordance with the property provisions of the contract.

Al1. Government-furnished property must be inspected and checked promptly. At the time of recelpt, any visible or other external evidence of damage or error in quantity ohould be noted on the wayblll with the signature of the carrier's agent. As soon as possible, the contractor must send the Contracting officer a full report of the damage or quantity error, including extent, apparent 
cause, and the estimated cost of repalrs. The Contracting officer will advise the contractor of the. action to be taken.

It is the contractor's responsibility to inspect, at the time of recelpt, all property not furnished by the Government that is acquired in the performance of the contract, and to take any necessary action with the vendor and/or carrier if there should be any damage or error in quantity.

\section{Contractor's Liablifty}

Subject to the terms of the contract, the contractor may be llable when shortages of Government property are disclosed, when Government property is lost, damaged, destroyed, or stolen, or when there is evidence of Improper or unreasonable use or consumption of Government property.

The contractor is required to promptly report to the Property Administrator any loss, damage, or destruction to Government property in his possession or control, or in the possession or control of any subcontractor, together with all the facts and circumstances of the case. See Retirement of Property, Subpart 6 E.

Any loss that may be due to theft must be reported by the contractor 1 mmediately to the local police and/or the Federal Bureau of Investigation and the Property Adrinistrator.

E. Segregation of Government-owned Property

Ordinarily, provisions shall be made by the contractor to keep Government property segregated from contractor-owned property. Commingling of Government-and contractor-owned property may be allowed only when the segregation of the property would materially hinder the progress of the work, (e.8., segregation is not feasible for reasons such as quant1ties, lack of space, or costs caused by additional handling), and where control procedures are adequate, 1.e., the Government property is identified as being 
Government property. Commingling must be approved in advance by the Property Administrator.

F. Phystcal Protection of Property

Controls such as property pass systems; memorandum records, marking of tools, regular or intermittent gate checks and perimeter fencing shall be $1 \mathrm{mplemented,}$ recognizing the value of the property, to prevent loss, theft, or unathorlzed movement of property from the premises on which-such property is: located.

Classifled property will be handled in accordance with inetructinns of the Contracting officer.

G. Control of Sensitive Items of property.

The contractor shali assure that effective procedures and practices are established.for:the administrative and phystcal control of sensitive property ltems before and after 1ssuance. Each contractor shall prepare a list of the types of property considered to be sensitive." This 11st, together with control procedures; shall be provided to the Property Administrator for review and approval.

As a minimum, controls on sensitive property shall include memorandum recelpts, bin or tool check systems, or combinations thereof. Procedures:shall provide for physlcal inventorles at least once each year, and methods for adjustment of inventory levels due to losses, thefts and damages. Such procedures and practices shall be subjecl lo reviow by the property Adointstrator.

H. D1sposition

The contractor is responstble for disposing of Government property as provided for in the contract or as directed by the contracting officer. It is also the duty of the contractor to promptly advise the property Administrator of any Government property that becomes excess to requirements for contract performance and to take such action for its disposition as directed. 


\section{Relief from Responsib111ty}

Subject to instructions of the Contracting officer and the terms of the contract, the contractor may be relieved of responsiblitiy.for/Government property as follows:

1. Property consumed or expended in contract performance--to the extent the contracting officer has determined that 1 ts consumption or expenditure was for proper purposes and in reasonable quantity for performance of the contract;

2. Property removed from contractor's possession--when removed as directed by the Property Administrator or Contracting officer;

3. Property lost, damaged, destroyed, etc., (1ncluding property consumed or expended in excess of reasonable requirements, and non-severable Government-owned property which has been connected to contractor-owned property for the performance of the contract and cannot be removed without destroying its serviceability)--when the Contracting officer has determined the contractor's liablitiy, if any, the Government has been relmbursed to the extent required by the Contracting officer's determination, and proper disposition. has been made of any property rendered unserviceable by damage. 
Subpart 2--Records.

\section{A. Scope}

This subpart establishes minimum requirements for records to be established and maintained by the contractor for Government property in his possession or control.

\section{B. General}

1. The cuntractor ohall establish and malntain adequate detalled property records, either manual or mechanized and consistent with the requirements of this Gulde, for all Government property provided under a contract, including property provided under such contract as may be in the possession or control of a subcontractor.

2. The property records shall indicate the status of Government property at any state of completion of the work under a contract.

3. If a contractor has multiple contracts with DOE, separate property records for each contract are desirable; however, a consolidated property record may be maintained if it provides the pertinent information set forth in this subpart.

4. Property records of component equipment items which would have been established if they had been acquired. separately shall be established for such usable components which are replaced or removed as a result of modification or otherwise.

5. The contractor 8 property control system shall Include an adequate locator system or technique for locating each item of Government property.

\section{Pricing}

The unit cost of each item of Government property must be contained in the contractor's property control 
-

system. Unless the contractor's quantitative inventory record contalns unit cost, the supplementary records containing this information must be Identified and recognized as a part of the officlal property records. For Government-furnished property, coples of documents needed for record purposes, including pricing, will be furnished to the contractor by the Property Administrator.

For property record purposes, or 1 iginal transportation and Installation costs are to be considered as part of the unit cost of an 1tem. Subsequent costs incurred in transporting and/or installing transferred or relocated property should not be added to the original acquisition cost.

\section{Records of Capital Equipment}

For each item of capital Government-owned equipment (as defined in Part I of this Guide), the contractor is required.co malntain an individual item record containing the following information as a minimum:

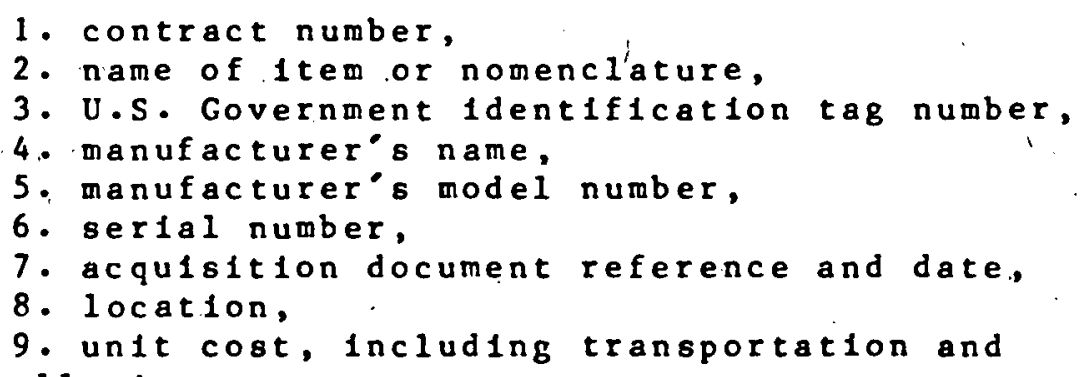
Installation.

Accessory and auxiliary items that are attached to, part of, or acquired for. use with a specific item of capital equipment must be recorded on the record of the basfc item. Any accessory or auxiliary item that is not attached to, part of, or acquired for use with a specific item of capital equipment must be recorded separately. Useable accessory and auxiliary items that are removed from items of Government equipment must also be separately recorded, and the cost of the basic 1 tem reduced proportionally. 
E. Records of Materials Malntained in Stock

Records of material maintalned by the contractor in stocks, or stores, and held under inventory control, shall. contain the following information:

1. Contract: number

2. Nomenclature ul lescription of $1 \mathrm{tcm}$

3. Quantity recelved

4. Quantity issued

5. Balance on hand

6. Posting reference and date of transaction

7. Unit. $\operatorname{cose}$

8. Dispustition 
Subpart 3--Identification

\section{A. Scope}

This subpart establishes minimum requirements for the Identification and marking of capital Government equipment in the possession or control of the contractor.

\section{B. General}

The contractor shali identify, mark, and record all capital equipment promptly upon receipt, except leased or rented equipment, and shall maintain this identification as long as it remains in the custody, possession, or control of the contractor. Property identification numbers will be recorded on all applicable recelving, shipping, and disposal documents, and any other documents pertaining to the property control system where practicable. Marking and numbering shall be accomplished by etching, stamping, painting, attaching metal or plast lc tags or decalcomanias. Information on property numbers will be furnished by the Property Aduinistrator. If practicable, such markings shall be removed or obliterated from the property Involved when Government ownersh1p is terminated. Leased or rented equipment shall be ldentified with tags which will not damage the property. Property which by 1 ts nature or size cannot be marked shall not be commingled with contractor-owned property unless approved by the Property Adoinistrator. Where items are not susceptible to marking, they shall be subject to other specific control measures, such as custodial receipts. 
Subpart 4--Physical Inventorles

A. Scope

Th1s subpart establishes minimum requirements for the physical inventory of Government property in the possession or control of the contractor and subcontractor.

B Genera1

The contractor is required to physlcally inventory Government property in his pussession or control and to require such inventul les of property hold by subcontractors. The physical inventory shall be consistent with approved contractor procedures and generally accepted accounting principles. Procedures that are $11 \mathrm{mited}$ solely to a check-off of a listing of recorded property do not meet the requirements of a physical inventory.

C. Frequency

Physical inventories of capital equipment are to be taken not less frequently than every 2 years, except that Inventories of sensitive itens shall be taken annualiy. Substantial quanttties of material (stores) held under inventory control shall be inventoried annually. Small quantities of materlal representing bench stock need not be inventoried.

D. Reporting Results of Inventories

The contractor shall, as a minlmum, submit to the Property Administrator a listing of all discrepancies disclosed by a physical inventory, and a signed statement that the physical inventory of all Government property was completed on a certain date and that the official property records were found to be in agreement with the physical inventory, except for the discrepancies reported. The $118 \mathrm{ting}$ and signed statement shall be furnished with a minimum of,delay after completion of the physical inventory. 
E. Records and Reports

Inventory procedures shall include a requirement that Inventory personnel note and report equipment ltems obviously unserviceable, not being used, or cannlibalized. The procedures should also provide for use of such reports as the basis for a follow-up review when necessary.

Appropriate inventory records and reports shall be maintained and will serve as a basis for (1) effecting maximum utilization of avallable property, including excess, (2) prompt identification and reporting of excess property, (3) effective physical protection of property, and ( 4$)$ the preparation of speclal and recurring reports. Full use will be made of accounting records and reports to avold duplication.

F. Inventories Upon Termination or Completion

Immediately upon termination or completion of a contract, the contractor shall submit an inventory report adequate for determining appropriate disposal of all Government property applicable to the terminated or completed contract. Further, this report shall include an Inventory report of all Government property in a subcontractor's possession or control which is also applicable to the terminated or completed contract. This inventory report will be submitted to the Property Administrator for verification and disposition action. The requirement for physical inventory of Government property at the completion of a contract may be walved by the contracting officer. When the property applicable to the completed contract is authorlzed for use on a follow-on contract, provided:

1. past experience has established the adequacy of property controls, and

2. A statement is provided by the contractor indicating that transfer of record balances has been made in lieu of preparing a formal inventory list and the contractor accepts responsibility and accountability for these balances under the terms of the follow-on contract. 
Subpart 5--Care and liaintenance

A. Scope

This subpart establishes minimum requirements as to "care and maintenance of Government property in the possession or contrnj nf the contractor and subcontractor. See Part II for special requirements for motor velifies.

B. General

The contrartor shall be responstble for the p.roper care and malntenance of Government property in his possession or control from the time of recelpt of the propercy until properly relieved of responsibility in accordance with the contract. The removal of Government property to storage, or its contemplated transfer, does not relieve the contractor of these responsibilities.

C. Contractor's liarnenance Program

The contractor's maintenance program shall be consistent with sound economic industrial practice, the manufacturer"s recommendation, and the terms of the contract, including the following:

1. Preventive Maintenance: Preventive maintenance is generally performed on a regularly scheduled basis in order to detect and correct unfavorable conditions or defects before they result in breakdor s and to maximize the useful life of the equipment. An effective preventive maintenance program shall consist of, but not be limited to, the following:

(a) inspecting equipment at such periodic Intervals to detect maladjustment, wear, or impending breakdown;

(b) regularly scheduled lubrication of bearings and moving parts in accordance with a lubrication chart or equivalent plan;

(c) adjustments for wear, repalr, or replacement of worn or damaged parts and the elimination of causes of deterioration and assoclated parts; 
(d) removal of sludge, chips, and cutting olls from equipment which will not be used for a period of time;

(e) taking necessary precautions to prevent deterforation from contamination and corrosion; and

(f) proper storage and preservation of accessories and special tools furnished with an 1 tem of plant equipment but not regularly used with it.

2. Pafor Repalrs or Pehabilitation: The contractor s maintenance program shall provide for the disclosure and reporting of the need for major repalrs, replacement, and other rehabilitation work on Government property in the possession or control of the contractor.

3. Records of Maintenance: The contractor's maintenance.program shall provide for records sufficient to disclose the malntenance and repalr performed and associated costs. 
Subpart 6--Utilization, Disposal and Retirement

A. Scope

This oubpart establishes minimum requirements for the utilization, disposal, and retirement of Government property in the possession or control of the contractor and subcontractor.

\section{B. General}

It is DOE contrace shall be utilized to the fullest extent possible. The contractor's procedures shall be adequate to assure that Government property will be utilized only for those purposes authorlzed in the contract, and that the Contracting Officer ${ }^{\circ}$ approval is obtained for noncontract use.

C. Maxtmum Use of Property

Property and supply managent practices shall assure that the maximum and best possible use is made of property. Materials and equipment shall be 11 inted to those ltems essential for effective execution of work performed under the contract.

D. D1sposa 1

Contractors having property determined to be excess, unless otherwise authorlzed, shall contact the property Adminfstrator for instructions as to the proper method of disposal. Property shall not be disposed of without prior approval of the Contracting officer.

\section{E. Retirement of Property}

When Government property is worn out, lost, stolen, destroyed, abandoned or damaged beyond economical repalr, it shall be listed on a retirement work order. A full explanation shall be made, supported by an Investigation, If necessary, as to the date and circumstances surrounding loss, theft, destruction, 
abandonment or damage. The retirement work order shall be signed by the responstble administrative official inftiating the report and reviewed and approved by an official at least one supervisory echelon above the official initiating the report, and the property Administrator.

Detalled information concerning the retention and/or submission of retirement work orders will be furnished by the Property Administrator. 
Part III

MOTOR VEHICLE MANAGEMENT

\section{A. Scope}

The preceding parts of this Guide apply to Government owned vehicles in a general way and are not repeated in this part except where necessary to clarify differences. The following guldance applies only to Government furnished vehicles.

B. Pol1cy

1. Government furnished motor vehicles may be DOE-owned vehicles, vehicles leased from the General Services Administration Interagency Motor Pools (GSA-IMP's), and/or vehicles leased from commercial sources. It is DOE policy to fully conform to the average fuel economy standards as pronulgated by GSA in the Federal Property lianagement Regulations (see D. Limitations) in any selection of such Government furntshed vehicles.

2. Motor vehicles will not be acquired for or furnished to fixed-price contractors except in the most unusual c1rcumstances and then, only after the approval of the DOE Director of Procurement and Contracts Management Directorate has been obtained.

3. Use of GSA-IMP's by fixed-price contractors must be approved by the Admintstrator of GSA; requests, with appropriate Justification, for such approvals will be submitted by the Contracting officer to the DOE Director of Procurement and Contracts Management Directorate prior to submission to GSA.

4. Furnishing DOE-owned vehicles to contractors or DOE offices in areas served by GSA-IMP's requires GSA approval. Requests for such approval will be submitted through the Contracting officer to the DOE Director of Procurement and Contracts Management Directorate and w11 be supported by a statement from the applicable GSA 
Region indicating that GSA cannot provide the required service.

5. Government furnished vehicles, whether leased or owned, are to be used for officlal purposes only.

\section{Definitions}

Because ot differences in controls or limitations on possession and use of government vehicles, such vehicles are classified as follows:

1. Passenger vehiclco

a. Passenger auromob1les
(1) sejáns
) omall, oubcompact, compact, mid-size
(2) station wagons)
\} and large.
b. Ambulances
c. Buses

2. Trucks
a. $4 \times 2$, less than 10,000 GVWR )
b. $4 \times 4$, 1ess than 10,000 GVWR $11 \mathrm{ght}$
c. $4 \times 2$, greater than 10,000 GVWR )
d. $4 \times 4$, greater than 10,000 GVWR?
f medium and heavy

3. Special purpose vehicles

a. Fire trucks

b. Construction vehicles

c. Other vehicles equipped for special purposes.

\section{L1m1tations}

1. The types of passenger automobiles which. DOE may acquire generally are limited to small, subcompact, and compact types in order to meet. Federally established average fuel. economy standards. All purchase requisitions for such vehicles must be certified by the Procurement and Contracts lianagement Directorate prior to submission to CSA for procurement action. Certification also is required prior to the lease of passenger automobiles. 
2. The price which DOE may pay for passenger automobiles each year is $11 \mathrm{mlted}$ by statute.

3. The number of passenger vehtcles (sedans, station wagons, ambulances and buses). which DOE may own and the number which it may purchase each year are also $11 \mathrm{~m} 1 \mathrm{ted}$ by statute.

4. Based on requirements subnitted by DOE field organizations in their budget submissions, DOE allocates to the fleld organizations a specific number of authorizations for replacement or additional passenger vehicles each year.

5. Passenger vehicles acquired from excess or on loan from other agencles for more than three months, or via transfer, count as part of the $11 \mathrm{mited}$ annual allocation and as part of the limited fleet size.

6. The statutory limitations on price and quantity of passenger vehicles indicated above do not apply to trucks. The type, number, and cost of trucks which DOE may buy and furnish to a contractor depend on the terms of the contract; the same is true of special purpose vehicles.

7. When the Contracting officer so directs, DOE-owned vehicles may be disposed of as exchange sale 1 tems, In which case the T1tle Transfer Instrument, Standard Form 97 , must be executed by a DOE off 1 c1al who has been designated in writing to execute the Title Transfer Form.

\section{E. Purchase Procedures}

1. GSA has the responsibility for procurement of motor vehicles for Government agencies.

2. Depending on terms of the contract, the contractor may submit his requirement for vehicles to the Contracting officer or, if the latter directs, may forward the requisition to GSA as indicated in Part III D.1., In whlch case the contractor acts as an agent of DOE. 
3. Requisitions are accomplished by use of standard Form 1781, Motor Vehicle Requisition, Delivery order and Invoice. The appropriate GSA address is printed on the form.

(a) Federal Standard No. 122 and FSC 2310 define sedans and station wagons.

(b) Federal Standards Nos: 292 and 307 , and FSC 2320 define $11 \mathrm{ght}$ trucks.

4. The total time for GSA to process requisitions and to contract for acquisition and delivery of vehicles depends to some extent on when the purchase order or requisition is received by GSA. The time from purchase order to dolivery nf light vehicles may require as long as one year, and as long as two years for medium, heavy and special purpose vehfcles.

Vehicles acquired under a cSA contract will be thoroughly examined for defects upon recelpt. Any defect shall be promptly reported to GSA and repairs shall be made under terms of the warranty.

\section{F. Use of GSA Interagency liotor Pools}

1. GSA-INP's provide the following:

(a) motor vehicles on a trip or daily assignment

(b) motor vehicles on Indefinite (long-term)

assignment

(c) commercially rented vehtcles for short-term

use

(d) shuttle, taxicab and bus services

(e) other services lncluding maintenance,

storage and service station services for

Government-owned vehicles not under GSA control.

2: Once authority 18 recelved for use of GSA-IMP vehicles, the contracting officer, or such other person as he designates, requests (by letter, memorandum, teletype, requisition, purchase order or similar document) the desired service from the local IMP. A complete billing address must accompang the request. 
3. After the IMP agrees to provide the service, oral requests by properly ldentified personnel will be accepted.

4. If the local IMP cannot provide the requested services or if the services provided do not satisfy the need, a statement of the situation and a request for assistance should be sent. to the GSA Regional office with a copy to the DOE Director of Procurement and Contracts Management Directorate. If the GSA Region cannot satisfy the requirement, the Contracting officer should consider commerclail leasing, purchase or use of contractor-owned vehicles.

For purchase of: vehicles for use in an area supported by an IMP, a request with fustification,. Including a statement: of $\mathrm{GSA}^{\circ}$ s Inablitty to provide the service, should be forwarded to the DOF Director of Procurement and Contracts Management Directorate by the Contracting officer.(see B.3.) prior to submission to GSA.

\section{G. Tags, Legend and Identification}

1. Except as Indicated below, DOE-owned vehicles and. vehicles leased for tore than 60 continuous days will have Government tags. and the legend:

$$
\begin{gathered}
\text { For Officlal Use Only } \\
\text { U.S. Covernment } \\
\text { Department of Energy }
\end{gathered}
$$

which is to be displayed as specified by the. Property Administrator.

2. Security Vehicles may be exempted from the above requirements by Heads of Field offices and the Director of Administration; Headquarters. Vehicles leased for 6 months or less for off-road usage-are required to have Government tags but may be exemped from use of the legend and 1dentification. All other exemptiong require. approval by the DOE D1rector of Procurement and Contracts Management Directorate. 
H. Maintenance (see Part II, Subpart 5)

Government-owned vehicles are to be maintained according to a systematic written procedure, and in accordance with manufacturer specifications and the terms of the warranty. The "Guide for the Preventive liaintenance of Motor Vehicies," published by GSA; is avallable for the guidance of all those responsible for maintenance of Government-owned vehicles.

\section{Official Use only}

Based on statutes, Government-owned vehicles are to be used for "Ufficlal Use Only." Work-to-home or home-to-wurk transportation on a continuing basis requires approval of the Heads of Field offices or the Director of Administration, Headquarters. A llead of a Division or Office in DOE Headquarters may approve home-to-work transportation on a one-time exceptional basis. The approval responsibllity cannot be delegated except for a one-trip basis. Records of the approvals for home-to-work transportation will be kept on file.

\section{J. Reports}

For DOE-owned vehicles assigned to concractors the following annul fiscal year-end reports are required as specified by the Property Administrator:

(a) Agency Report of Notur Vehiele Data;

Standard Form 82

$82 \mathrm{~d}$

(b) Agency Report of Sedan Data; Standard Form

(c) Special Purpose Vehicle Report

(d) Age and Mileage Analysis

\section{R. Alrcraft}

Acquisition of an alrcraft requires statutory authority, usually a line ltem approval in the annal DOE appropriation act. When a lease, rental, hire, or loan of an alrcraft exceeds 30 days, approval for the lease must be recelved from the DOE Director of Procurement and Contracts Management Directorate. The "Officlal Use Only" limitations for motor vehicles also apply to alrcraft usage. 